\title{
Evidence That Insulin Resistance Is Responsible for the Decreased Thermic Effect of Glucose in Human Obesity
}

Eric Ravussin, Kevin J. Acheson, Olivier Vernet, Elliot Danforth, and Eric Jéquier Institute of Physiology, University of Lausanne, CH-1011 Lausanne; Nestec Ltd., Research Department, CH-1800 Vevey, Switzerland; and University of Vermont, Burlington, Vermont 05405

\begin{abstract}
The thermic effect of glucose was investigated in nine obese and six lean subjects in whom the same rate of glucose uptake was imposed. Continuous indirett calorimetry was performed for $\mathbf{2 4 0}$ min on the supine subject. After $\mathbf{4 5} \mathrm{min}, \mathbf{2 0 \%}$ glucose was infused (609 $\mathrm{mg} / \mathrm{min}$ ) for $195 \mathrm{~min}$ and normoglycemia was maintained by adjusting the insulin infúsion rate. At $2 \mathrm{~h}$, propranolol was infused (bolus $100 \mu \mathrm{g} / \mathrm{kg} ; 1 \mu \mathrm{g} / \mathrm{kg} \cdot \mathrm{min}$ ) for the remaining $75 \mathrm{~min}$.

To maintain the same glucose uptake $(0.624 \mathrm{~g} / \mathrm{min})$, it was necessary to infuse insulin at $3.0 \pm 0.6$ (leans) and $6.6 \pm 1.2 \mathrm{mU} /$ $\mathrm{kg} \cdot \mathrm{min}$ (obese) $(P<0.02)$. At this time, glucose oxidation was $0.248 \pm 0.019$ (leans) and $0.253 \pm 0.022 \mathrm{~g} / \mathrm{min}$ (obese) (NS), and nonoxidative glucose disposal was $0.375 \pm 0.011$ and $0.372 \pm 0.029$ $\mathrm{g} / \mathrm{min}$, respectively. Resting metabolic rate (RMR) rose significantly by $0.13 \pm 0.02 \mathrm{kcal} / \mathrm{min}$ in both groups, resulting in similar thermic effects, i.e., $5.5 \pm 0.7 \%$ (leans) $5.4 \pm 0.9 \%$ (obese) (NS) and energy costs of glucose storage $0.35 \pm 0.06$ and $0.39 \pm 0.09$ $\mathrm{kcal} / \mathrm{g}$ (NS), respectively. With propranolol, glucose uptake and storage remained the same, while RMR fell significantly in both groups, with corresponding decreases $(P<0.05)$ in the thermic effects of glucose to $3.7 \pm 0.6 \%$ and $2.9 \pm 0.8 \%$ (NS) and the energy costs of glucose storage $0.23 \pm 0.04$ and $0.17 \pm 0.05 \mathrm{kcal} / \mathrm{g}$ (NS) in the lean and obese subjects, respectively. These results suggest that the defect in the thermic effect of glucose observed in obese subjects is due to their insulin resistance, which is responsible for a lower rate of glucose uptake and hence decreased rate of glucose storage, which is an energy-requiring process.
\end{abstract}

\section{Introduction}

That obesity is the result of a positive energy balance due to energy intake exceeding energy expenditure at some time in an obese subject's life has never been questioned. However, whether the positive energy balance is caused by gluttony, sloth, or one or several metabolic defects has stimulated much research over the last $20 \mathrm{yr}$.

More recently, the observation by Rothwell and Stock (1) that brown adipose tissue is involved in dietary-induced thermogenesis and that it is defective in genetically obese (2) and ventromedial hypothalamic lesioned obese rodents (3) has led to increased interest in the energy expenditure term of the energy balance equation. While it is reasonably well established that brown adipose tissue and the sympathetic nervous system are involved in rodent models of obesity, a defective thermogenic

Received for publication 18 December 1984.

J. Clin. Invest.

(c) The American Society for Clinical Investigation, Inc.

$0021-9738 / 85 / 09 / 1268 / 06 \$ 1.00$

Volume 76, September 1985, 1268-1273 response to meal ingestion in human obesity is more controversial.

Pittet et al. (4) demonstrated that the thermic response to the ingestion of glucose was decreased in obese compared with lean subjects. This observation was supported by Golay et al. (5), and similarly the thermic effect of a mixed meal has also been found (6-9) to be lower in the obese than in lean subjects. On the other hand, Felig et al. (10) did not find a decreased thermic effect of a mixed meal in obese women, which has been confirmed by others $(11-13)$. The reasons for these conflicting results are not known; however, the heterogeneity of the obese individuals who have been studied, particularly in regard to insulin resistance and glucose metabolism, has not been sufficiently taken into account.

In studies that have used the glucose-clamp technique, obese and/or diabetic patients had decreased rates of glucose uptake for a given rate of insulin infusion (14). Since much of the thermic effect of infused glucose can be accounted for by the obligatory cost of glucose storage (14-17), it is conceivable that any decrease in thermogenesis in response to the ingestion and/or infusion of glucose in the obese could be due to a decreased rate of glucose uptake by the tissues. Hence, this thermogenic defect appears to be a defect more likely in glucose uptake or storage rate rather than to a fundamental difference in the efficiency of glucose use.

To test this hypothesis, we performed a glucose-clamp study in which glucose uptake and storage rates were matched in obese and lean subjects by infusing more insulin in the obese. In these conditions, similar increases in energy expediture were observed in both groups, which resulted in similar costs of glucose storage. Furthermore, the sympathetically mediated component of the thermic effect of glucose (facultative thermogenesis) was found to be similar in the lean and the obese subjects by administration of propranolol. Therefore, we hypothesize that the low thermic effect of glucose in obese subjects that has been reported elsewhere is related to insulin resistance and a decreased rate of glucose storage.

\section{Methods}

Subjects. 15 subjects were studied, 9 of whom were moderately obese, while 6 lean subjects served as controls. Their physical characteristics are presented in Table $I$. The obese men were chosen as having $>25 \%$ and the women $>30 \%$ body fat. In the control group the men were chosen as having $<20 \%$ and the women $<25 \%$ body fat as estimated by skinfold measurements (18).

The experimental protocol was reviewed and accepted by the hospital ethical committee. None of the subjects were taking any medication before the test and none of them had a medical history of asthma or a family history of diabetes.

Procedure. Each subject slept the night before the experiment at the Institute. After a 10-h overnight fast, the subject was awakened at 6.30 a.m. After voiding, he or she was transfered to the test room where two venous lines were inserted, one into an antecubital vein for the infusions and the other into a hand vein for blood sampling. The hand was then 
Table I. Physical Characteristics

\begin{tabular}{lcc}
\hline & Controls* & Obeseł \\
\hline Sex $(M / F)$ & $3 / 3$ & $2 / 7$ \\
Age $(y r)$ & $30(24-38)$ & $27(21-35)$ \\
Height $(\mathrm{cm})$ & $171(160-181)$ & $165(144-183)$ \\
Weight $(k g)$ & $62(53-69)$ & $75(61-95)$ \\
Body fat $(\%)$ & $19(11-24)$ & $33(26-39)$ \\
\hline
\end{tabular}

* Body fat $<20 \%$ for males (M) and $<25 \%$ for females (F).

$\ddagger$ Body fat $>25 \%$ for males and $>30 \%$ for females.

placed in a box heated at $60-70^{\circ} \mathrm{C}$ to achieve arterialization of the venous blood. Both lines were kept patent with physiological saline.

$20 \mathrm{~min}$ later, continuous respiratory exchange measurements began and were performed over the next $4 \mathrm{~h}$ on the supine subject using an open-circuit, ventilated-hood, indirect calorimeter. After 45 min of baseline measurements, a priming dose of insulin was given in a logarithmically decreasing manner and a $20 \%$ glucose solution was infused to maintain normoglycemia. Over the next $30 \mathrm{~min}$, the $20 \%$ glucose infusion was increased until a constant rate of $0.609 \mathrm{~g} / \mathrm{min}$ was achieved in all subjects. At the same time the insulin infusion was varied to maintain euglycemia. Thus all subjects had the same glucose uptake or " $M$ " value $(\mathrm{g} / \mathrm{min})$ by varying the rate of insulin infusion to maintain the constant glucose uptake. After $2 \mathrm{~h}$ of glucose clamp, a prime continuous infusion of propranolol $(100 \mu \mathrm{g} / \mathrm{kg}$ and $1 \mu \mathrm{g} / \mathrm{kg} \cdot \mathrm{min})$ was begun and continued for a further $75 \mathrm{~min}$.

Arterialized venous blood samples were taken at $-30,-10,80,120$, 180 , and $195 \mathrm{~min}$ and analyzed for plasma catecholamines $(19,20)$ insulin (21), and free fatty acids (22). Plasma propranolol concentrations were analyzed on the 195-min sample (23). During the entire glucose-clamp procedure, samples were taken at 5-min intervals for plasma glucose determinations in duplicate using the glucose oxidase method on a glucose analyzer (model II, Beckman Instruments, Inc., Fullerton, CA). Urine was collected just before and at the end of the test for nitrogen analysis (24).

Data analysis. Glucose uptake and energy expenditure were measured continuously throughout the test. For data presentation, the last $30 \mathrm{~min}$ of each period from -30 to $0 \mathrm{~min}$ (base line), 90 to $120 \mathrm{~min}$ (glucose clamp), and 165 to $195 \mathrm{~min}$ (glucose clamp + $\beta$-blockade) were compared. The change in energy expenditure was calculated by subtracting the baseline value from the mean energy expenditure obtained in the other two 30 -min periods. Glucose and fat oxidation was calculated from the nonprotein respiratory quotient and the nonprotein oxygen consumption as described elsewhere (25).

The rate of "glucose storage" or nonoxidative glucose disposal was calculated by subtracting the rate of glucose oxidation from the rate of the corrected glucose uptake, i.e., by taking into account the changes in the glucose pool assuming a distribution volume of 0.21 liter $/ \mathrm{kg}$ body wt. However, under the steady state conditions of the study, this correction was of a small magnitude, and amounted to $1-3 \%$ of glucose metabolism. Hepatic glucose production was not measured in the present study and was assumed to be totally suppressed in both groups during glucose/ insulin infusion $(14,26)$.

The thermic effect of infused glucose-insulin was calculated by dividing the increase in energy expenditure $(\triangle \mathrm{EE})$ by the rate of glucose energy uptake: thermic effect infused glucose-insulin $=(\Delta \mathrm{EE} \mathrm{kcal} / \mathrm{min}) /$ $(M \times 3.75)$, where $M$ is the steady state glucose uptake in grams per minute and 3.75 is the energy value of a gram of glucose in kilocalories per gram.

\section{Results}

Fig. 1 illustrates the insulin infusion rates required to maintain a constant glucose metabolism of $0.624 \mathrm{~g} / \mathrm{min}$ in both groups.

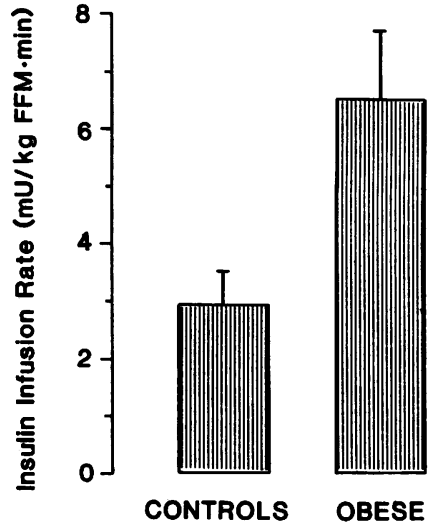

Figure 1. Index of insulin sensitivity in the six lean and nine obese subjects, given by the rate of insulin infusion $(\mathrm{mU} / \mathrm{kg}$ FFM $\cdot$ min) necessary to maintain euglycemia when $609 \mathrm{mg}$ / min glucose was infused at a constant rate (mean \pm SEM).

It can be seen that during the last 30 min of the clamp protocol, the infusion of $3.0 \pm 0.6 \mathrm{mU} / \mathrm{kg}$ FFM $\cdot \mathrm{min}$ insulin was necessary to maintain similar rates of glucose disposal in the lean compared with $6.6 \pm 1.2 \mathrm{mU} / \mathrm{kg} \mathrm{FFM} \cdot \min (P<0.02)$ in the obese subjects. This illustrates that although the obese subjects were not severely obese, they already exhibited a significant insulin insensitivity when compared with the lean subjects.

Basal plasma insulin concentrations were $8.4 \pm 1.9 \mu \mathrm{U} / \mathrm{ml}$ and $12.4 \pm 1.7 \mu \mathrm{U} / \mathrm{ml}$ in the lean and obese subjects, respectively. During the clamp they rose rapidly to $196 \pm 46$ and $353 \pm 89 \mu \mathrm{U} /$ $\mathrm{ml}$, respectively, and continued to rise progressively throughout, attaining values of $209 \pm 51$ and $434 \pm 118 \mu \mathrm{U} / \mathrm{ml}$ by the end of the test (Fig. 2). Basal plasma free fatty acid concentrations were similar in the two groups ( $402 \pm 41$ and $417 \pm 48 \mu \mathrm{mol} / \mathrm{liter}$, respectively) and were suppressed to a similar extent during the insulin infusion, reaching a plateau of $\sim 150 \mu \mathrm{mol} / \mathrm{liter}$ at 30 min, which persisted until the end of the test.

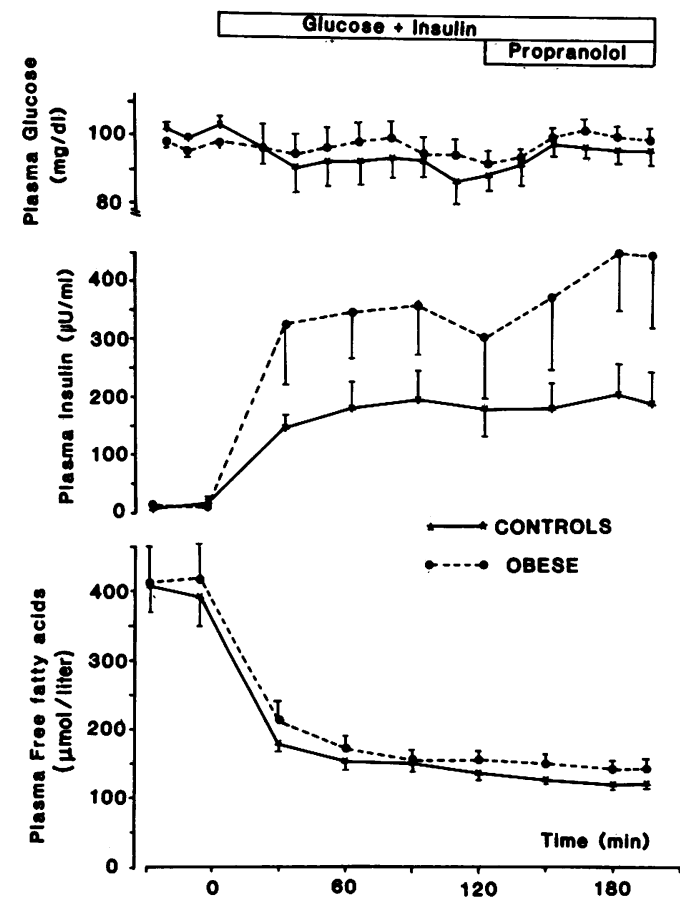

Figure 2. Changes in plasma glucose $(\mathrm{mg} / \mathrm{dl})$, insulin $(\mu \mathrm{U} / \mathrm{ml})$, and free fatty acids $(\mu \mathrm{mol} /$ liter) during the glucose-insulin infusion before and after $\beta$-adrenergic receptor blockade with propranolol (mean \pm SEM). 
Table II. Changes in Heart Rate Blood Pressure, Plasma Catecholamine, and Propranolol Concentrations during the Hyperinsulinemic Clamp Studies

\begin{tabular}{|c|c|c|c|c|c|}
\hline & Basal & $\Delta$ & Clamp & $\Delta$ & Clamp + Propranolol \\
\hline \multicolumn{6}{|l|}{ Lean subjects } \\
\hline Heart rate (beats/min) & $61 \pm 3$ & $*$ & $65 \pm 3$ & $\ddagger$ & $58 \pm 3$ \\
\hline Systolic blood pressure $(\mathrm{mmHg})$ & $117 \pm 3$ & $\ddagger$ & $120 \pm 3$ & $*$ & $116 \pm 3$ \\
\hline Diastolic blood pressure $(\mathrm{mmHg})$ & $73 \pm 3$ & $*$ & $68 \pm 2$ & (NS) & $65 \pm 2$ \\
\hline Norepinephrine $(\mathrm{pg} / \mathrm{ml})$ & $280 \pm 25$ & $*$ & $340 \pm 31$ & (NS) & $347 \pm 32$ \\
\hline Epinephrine $(p g / m l)$ & $76 \pm 9$ & (NS) & $78 \pm 10$ & (NS) & $75 \pm 6$ \\
\hline Propranolol $(n g / m l)$ & & & $59 \pm 9$ & & \\
\hline \multicolumn{6}{|l|}{ Obese subjects } \\
\hline Heart rate (beats/min) & $68 \pm 3$ & $\ddagger$ & $75 \pm 3$ & $\ddagger$ & $64 \pm 3$ \\
\hline Systolic blood pressure $(\mathrm{mmHg})$ & $119 \pm 3$ & (NS) & $119 \pm 3$ & $*$ & $114 \pm 2$ \\
\hline Diastolic blood pressure $(\mathrm{mmHg})$ & $73 \pm 3$ & $*$ & $69 \pm 2$ & $\ddagger$ & $64 \pm 3$ \\
\hline Norepinephrine $(p g / m l)$ & $260 \pm 13$ & $*$ & $281 \pm 12$ & $*$ & $310 \pm 12$ \\
\hline Epinephrine $(p g / m l)$ & $65 \pm 4$ & (NS) & $64 \pm 4$ & $\ddagger$ & $78 \pm 5$ \\
\hline Propranolol $(n g / m l)$ & & & $90 \pm 9$ & & \\
\hline
\end{tabular}

${ }^{*} P<0.05 . \quad \ddagger P<0.01$.

Table II presents the changes in heart rate and blood pressure observed during the three experimental periods. It can be seen that the supine heart rate was slightly lower in the lean than the obese subjects $61 \pm 3$ vs. $68 \pm 3$ beats/min (NS) and that the clamp caused significant increases in both groups to $65 \pm 3(P<0.025)$ and $75 \pm 3$ beats $/ \mathrm{min}(P<0.01)$, respectively. Propranolol administration significantly suppressed the heart rate to values below the basal levels in both groups $(P<0.01)$.

Significant changes in both systolic and diastolic blood pressure were observed in the lean subjects. While systolic blood pressure did not rise significantly during the clamp in the obese, it did decrease with propranolol. When the groups were compared no statistical differences were observed. Plasma norepinephrine rose significantly in both groups during the insulinglucose infusion and rose further with propranolol administration reaching significance in the obese group. At the end of the test, plasma propranolol levels were $59 \pm 9 \mathrm{ng} / \mathrm{ml}$ in the lean and $90 \pm 9 \mathrm{ng} / \mathrm{ml}$ in the obese $(P<0.05)$.

Fig. 3 presents the changes in plasma glucose concentration, glucose metabolized, glucose oxidation, and glucose storage during the test. It can be seen that plasma glucose concentrations were more variable than in a conventional clamp protocol, in which the insulin infusion rate is maintained constant and the glucose infusion rate is varied. This is due to the relatively prolonged effect of insulin on glucose metabolism. During the glucose clamp period (90-120 min), the rate of glucose metabolism (Table III) was $0.624 \pm 0.008 \mathrm{~g} / \mathrm{min}$ or $10.1 \pm 0.1 \mathrm{mg} / \mathrm{kg} \cdot \mathrm{min}$ in the lean and $0.624 \pm 0.012 \mathrm{~g} / \mathrm{min}$ or $8.4 \pm 0.2 \mathrm{mg} / \mathrm{kg} \cdot \mathrm{min}$ in the obese subjects. At this time, the rate of glucose oxidation was $0.248 \pm 0.019 \mathrm{~g} / \mathrm{min}$ and $0.253 \pm 0.022 \mathrm{~g} / \mathrm{min}$ (NS), respectively. During the last $30 \mathrm{~min}$ of the glucose clamp $+\beta$-blockade $(165-195 \mathrm{~min})$, glucose metabolism was $0.615 \pm 0.009$ and $0.621 \pm 0.005 \mathrm{~g} / \mathrm{min}$ and glucose oxidation $0.234 \pm 0.012$ and $0.229 \pm 0.017 \mathrm{~g} / \mathrm{min}$ in the control and obese subjects, respectively.

The increase in energy expenditure above the baseline values is shown in Fig. 4. The upper section of the figure presents the individual changes and the lower portion the mean changes in energy expenditure during the glucose-clamp and glucose clamp- plus- $\beta$-blockade periods. The base-line resting metabolic rate, was $1.10 \pm 0.07 \mathrm{kcal} / \mathrm{min}$ (lean) and $1.16 \pm 0.08 \mathrm{kcal} / \mathrm{min}$ (obese) (NS). In both groups, a steady-state uptake of $0.624 \mathrm{~g} / \mathrm{min}$ glucose caused a significant increase in energy expenditure to $1.23 \pm 0.07$ $\mathrm{kcal} / \mathrm{min}(P<0.005)$ and to $1.28 \pm 0.08 \mathrm{kcal} / \mathrm{min}(P<0.001)$ in the lean and obese subjects, respectively. When propranolol was infused, energy expenditure decreased to $1.18 \pm 0.08 \mathrm{kcal} /$

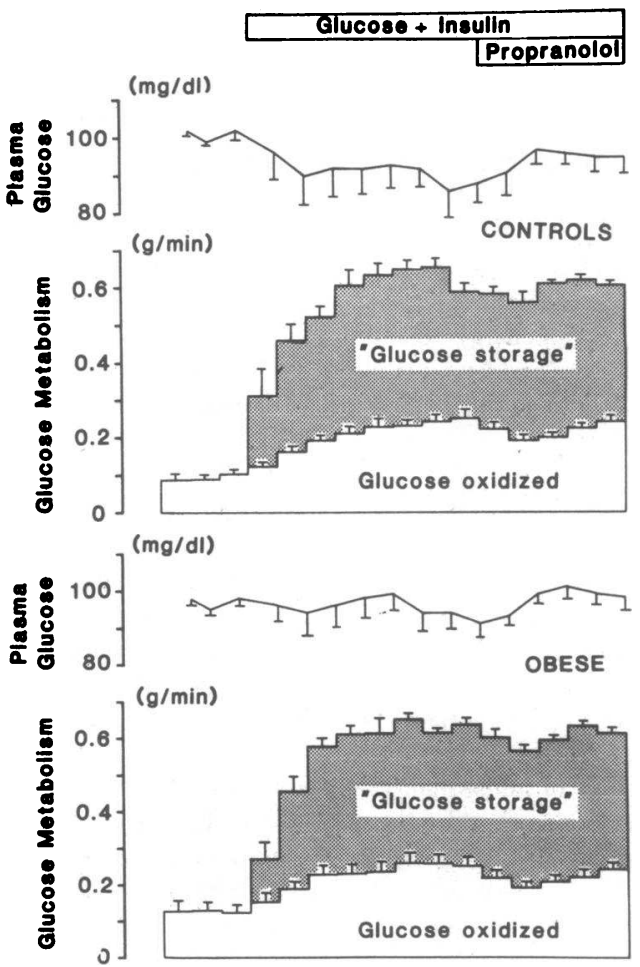

Figure 3. Blood glucose $(\mathrm{mg} / \mathrm{dl})$ and the contribution of glucose oxidation and glucose storage to the rate of total glucose uptake, which was maintained constant at $609 \mathrm{mg} / \mathrm{min}$ in the lean $(n=6)$ and the obese $(n=9)$ subjects before and after $\beta$-adrenergic receptor blockade with propranolol (mean \pm SEM). 


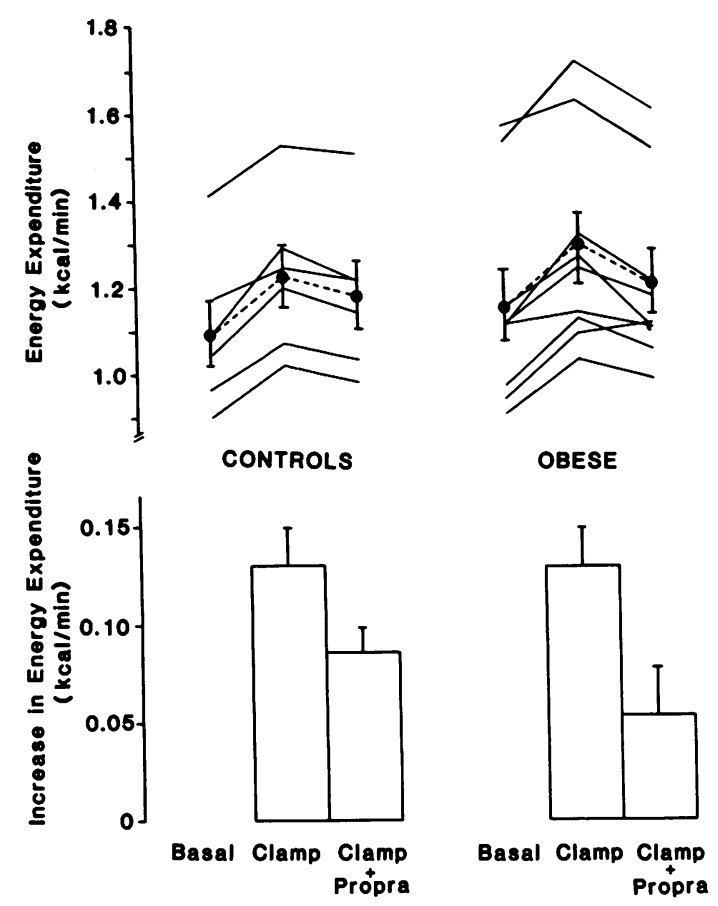

Figure 4. Individual (top) and mean changes (bottom) in energy expenditure $(\mathrm{kcal} / \mathrm{min})$ in the six lean and nine obese subjects, during a constant infusion of $609 \mathrm{mg} / \mathrm{min}$ glucose before and after $\beta$-adrenergic receptor blockade with propranolol.

$\min (P<0.005)$ and $1.21 \pm 0.07 \mathrm{kcal} / \mathrm{min}(P<0.005)$ in the two groups, respectively. As shown in Fig. 4 , this decrease was more variable in the obese subjects.

When these changes in energy expenditure were expressed as a function of the rate of glucose storage, the energy cost of glucose storage during glucose-insulin infusion was similar in the two groups: $0.35 \pm 0.06$ and $0.39 \pm 0.09 \mathrm{kcal} / \mathrm{g}$ in the lean and obese, respectively (NS) (Table III). When propranolol was infused, glucose storage remained the same but energy expenditure decreased $(P<0.001)$, such that the energy cost of glucose storage decreased to $0.23 \pm 0.04$ and $0.17 \pm 0.05 \mathrm{kcal} / \mathrm{g}$ (NS) in the lean and obese, respectively. Similarly, when the changes in energy expenditure were expressed as a function of the rates of energy uptake i.e., the thermic effect of infused glucose-insulin they were the same, $5.5 \pm 0.7 \%$ (leans) and $5.4 \pm 0.9 \%$ (obese), during the glucose clamp and were suppressed to the same extent with $\beta$-adrenergic-receptor blockade (Table III).

\section{Discussion}

The present study reinvestigates the thermic effect of infused glucose-insulin in lean and obese subjects using a new approach. Since obese subjects present various levels of insulin resistance and/or glucose intolerance, it is possible that the decreased thermic effect of ingested food (6-8), oral glucose $(4,5)$, or infused glucose (14) is related to the decreased glucose uptake observed in both obese and diabetic patients $(14,26)$. With this in mind, the present study was designed to infuse the same rate of glucose in lean and obese subjects while varying the rate of insulin infusion to obtain similar rates of glucose metabolism in both groups.

In a previous study, in has been shown that the increase in energy expenditure during the controlled conditions of a euglycemic hyperinsulinemic clamp can be divided into two components; an obligatory thermogenic component that is required for glucose storage, mainly as glycogen, and a facultative thermogenic component that is in excess of the obligatory demands and seems to be mediated by the sympathetic nervous system (14-17).

In this present study, in which similar rates of glucose uptake were imposed on lean and obese subjects, obligatory thermogenesis should be similar in both groups. Therefore, a reduced thermic effect of infused glucose-insulin would imply a difference in the sympathetically mediated facultative thermogenesis, which would also be shown by a lower suppression of thermogenesis by $\beta$-adrenergic blockade. However our results show that when the same amount of glucose enters the cells, the thermic response is the same in obese and lean subjects. Similarly, when the $\beta$ adrenergic receptors were blocked with propranolol, the decrease in energy expenditure was also similar and the energy cost of glucose storage fell to values commensurate with those calculated from a stoichiometric consideration of the number of moles of ATP required for glycogen synthesis (27).

Using the glucose-clamp technique, it has been shown that of the glucose that is metabolized, $\sim 80 \%$ is taken up by muscle, $\sim 10 \%$ by the liver and $\sim 1 \%$ by adipose tissue. The remaining $9 \%$ is taken up by insulin-independent tissues (28). Most of the glucose taken up by muscle should be converted to glycogen, since very little lactate production across the leg was observed during glucose-clamp conditions (28), and it has also been demonstrated that muscle glycogen synthase activation is strongly correlated with glucose storage (29).

There is, however, increasing evidence that a large proportion of liver glycogen is synthesized from three carbon compounds $(30,31)$, a more energy-wasteful pathway than the direct con-

Table III. Glucose Metabolism and Energy Cost of Glucose Storage

\begin{tabular}{|c|c|c|c|c|}
\hline & \multicolumn{2}{|l|}{ Glucose clamp } & \multicolumn{2}{|c|}{ Glucose clamp + propranolol } \\
\hline & Lean & Obese & Lean & Obese \\
\hline Glucose uptake $(\mathrm{g} / \mathrm{min})$ & $0.624 \pm 0.008$ & $0.624 \pm 0.012$ & $0.615 \pm 0.009$ & $0.621 \pm 0.005$ \\
\hline Glucose oxidation $(\mathrm{g} / \mathrm{min})$ & $0.248 \pm 0.019$ & $0.253 \pm 0.022$ & $0.234 \pm 0.012$ & $0.229 \pm 0.017$ \\
\hline Glucose storage $(\mathrm{g} / \mathrm{min})$ & $0.375 \pm 0.011$ & $0.372 \pm 0.029$ & $0.383 \pm 0.020$ & $0.391 \pm 0.019$ \\
\hline$\Delta$ Energy expenditure $(\mathrm{kcal} / \mathrm{min})$ & $0.13 \pm 0.02$ & $0.13 \pm 0.02$ & $0.09 \pm 0.01$ & $0.06 \pm 0.02$ \\
\hline Energy cost of glucose storage $(\mathrm{kcal} / \mathrm{g})$ & $0.35 \pm 0.06$ & $0.39 \pm 0.09$ & $0.23 \pm 0.04$ & $0.17 \pm 0.05$ \\
\hline Thermic effect of glucose-insulin (\%) & $5.5 \pm 0.7$ & $5.4 \pm 0.9$ & $3.7 \pm 0.6$ & $2.9 \pm 0.8$ \\
\hline
\end{tabular}


version of glucose to glycogen, which requires four rather than two ATP moles per mole of glucose. This would, at most, increase the obligatory cost of glucose storage by $\sim 10 \%$, if we assume that all hepatic glycogen deposition was the result of synthesis via $\mathrm{C}_{3}$-compounds. Whether the sympathetic nervous system modulates gluconeogenesis remains to be investigated.

If no obligatory and facultative thermogenic defects were apparent in the obese subjects, how do the present results relate to previous observations from our laboratory (4-6) and others (7-9), showing a decreased thermogenesis in response to the ingestion of glucose and/or a meal? Since glucose uptake is delayed in obese and diabetic subjects, the measurement of the thermic effect of glucose over short periods of, for example, $3 \mathrm{~h}$ could be a confounding factor, as the thermic effect is rarely terminated by the end of short intervals. Indeed, a recent study has shown that the tendency to a reduced thermic effect of food over the first $3 \mathrm{~h}$ following a meal was inversed during the next $3 \mathrm{~h}$ when obese and lean subjects were compared (13). Golay et al. (5) attempted to overcome this problem by correcting for the glucose in the glucose space at $3 \mathrm{~h}$ after $100 \mathrm{~g}$ glucose ingestion. However, even after this correction, a decreased thermic effect was apparent in obese subjects with insulin resistance or insulin deficiency.

The present study with intravenous glucose-insulin infusions shows that the thermic effect of glucose is related to its rate of uptake by the tissues. An insulin-sensitive lean subject has a glucose metabolism of $\sim 7 \mathrm{mg} / \mathrm{kg} \cdot$ min during the infusion of $1 \mathrm{mU} / \mathrm{kg} \cdot \mathrm{min}$ insulin $(14,17,32)$. Jacot et al. (33) found that glucose oxidation is saturated at $\sim 3 \mathrm{mg} / \mathrm{kg} \cdot \mathrm{min}$, whereas glucose storage continues to increase. Thus of the $7 \mathrm{mg} / \mathrm{kg} \cdot \mathrm{min}$ glucose metabolized, $\sim 4 \mathrm{mg} / \mathrm{kg} \cdot \mathrm{min}$ are directed towards storage, mainly as glycogen. Under similar conditions, an obese or diabetic subject has a lower overall rate of glucose metabolism, of the order of $2-5 \mathrm{mg} / \mathrm{kg} \cdot \min (14,26)$. Thus, the fate of most of the infused glucose needed to maintain euglycemia can be accounted for by "on-line" oxidation, leaving only a small amount for the energy requiring process of storage. Consequently, it would not be surprising to find a smaller thermic effect of glucose in these patients and possibly this could explain the decreased thermic effect of ingested glucose, even after correction for the glucose that had accumulated in the glucose space $3 \mathrm{~h}$ after its ingestion (5).

When the impairment of glucose uptake due to insulin resistance in obese subjects is overcome by infusing sufficient amounts of insulin, the thermogenic response to glucose is similar to that observed in lean individuals. This finding does not, however, exclude a reduced thermogenic response to glucose in obesity, but indicates that when glucose storage is matched by correcting the effect of insulin resistance, there is no intrinsic defect in the energetic cost of glucose disposal in obese individuals. Whether insulin per se has a thermogenic effect as suggested by Bogardus et al. (34) needs further investigation.

The present study emphasizes the relationship between the rate of glucose uptake and the corresponding thermogenic response. An elevated rate of glucose uptake favors glucose storage as muscle glycogen (33), an energy-requiring process, whereas a low rate of uptake allows, most of the administered glucose to be oxidized "on line," with the economy of the cost for glycogen synthesis. This mechanism may partially explain the reduced thermic effect of glucose observed in obese individuals with insulin resistance when glucose is administered either parenterally (14) or orally $(4,5)$. Even though the present study clarifies the mechanism of the decreased thermic effect of glucose in obesity, it does not provide insight into the pathogenesis of obesity itself; this question warrants further investigation.

The results of the present study suggest that the defect in the thermic effect of glucose observed in obese subjects, as conventionally measured, is due to the greater insulin resistance, lower glucose uptake, and decreased rate of glucose storage in these subjects.

\section{Acknowledgments}

The authors would like to thank Ms. D. Kock, E. Rossi, E. Maeder, and D. Penseyres for their technical assistance; Dr. T. Leemann for the plasma propranolol analyses; J. Braissant for secretarial help, and the Nestlé Co. 1800 Vevey, Switzerland for its financial support.

\section{References}

1. Rothwell, N. J., and M. J. Stock. 1979. A role for brown adipose tissue in diet-induced thermogenesis. Nature (Lond.). 281:31-35.

2. Trayhurn, P., R. M. Jones, M. M. McGuckin, and A. E. Goodbody. 1982. Effects of overfeeding on energy balance and brown fat thermogenesis in obese (ob/ob) mice. Nature (Lond.). 295:323-325.

3. Rothwell, N. J., and M. J. Stock. 1984. Brown adipose tissue. In Recent Advances in Physiology. P. F. Baker, editor. Churchill Livingstone, Edinburgh. 10:349-384.

4. Pittet, P., P. Chappuis, K. J. Acheson, F. de Techtermann, and E. Jéquier. 1976. Thermic effect of glucose in obese subjects studied by direct and indirect calorimetry. Br. J. Nutr. 35:281-292.

5. Golay, A., Y. Schutz, H. U. Meyer, D. Thiébaud, B. Curchod, E. Maeder, J. P. Felber, and E. Jéquier. 1982. Glucose induced thermogenesis in nondiabetic and diabetic obese subjects. Diabetes. 11:10231028.

6. Bessard, T., Y. Schutz, and E. Jéquier. 1983. Energy expenditure and postprandial thermogenesis in obese women before and after weight loss. Am. J. Clin. Nutr. 38:680-693.

7. Kaplan, M. L., and G. A. Leveille. 1976. Calorigenic response in obese and non-obese women. Am. J. Clin. Nutr. 23:1108-1113.

8. Schwartz, R. S., J. B. Halter, and E. L. Bierman. 1983. Reduced thermic effect of feeding in obesity: role of norepinephrine. Metab. Clin. Exp. 32:114-117.

9. Shetty, P. S., R. T. Jung, W. P. T. James, M. A. Barrand, and B. A. Callingham. 1981. Postprandial thermogenesis in obesity. Clin. Sci. (Lond.). 60:519-525.

10. Felig, P., J. Cunningham, M. Levitt, R. Hendler, and E. Nadel. 1983. Energy expenditure in obesity in fasting and postprandial state. Am. J. Physiol. 244:E45-E51.

11. Sharief, N. N., and I. MacDonald. 1982. Differences in dietaryinduced thermogenesis with various carbohydrates in normal and overweight men. Am. J. Clin. Nutr. 35:267-272.

12. Welle, S. L., and R. G. Campbell. 1983. Normal thermic effect of glucose in obese women. Am. J. Clin. Nutr. 37:87-92.

13. Schwartz, R. S., E. Ravussin, M. Massari, M. O'Connell, and D. C. Robbins. 1985. The thermic effect of carbohydrate versus fat feeding in man. Metab. Clin. Exp. 34:285-293.

14. Ravussin, E., C. Bogardus, R. S. Schwartz, D. C. Robbins, R. R. Wolfe, E. S. Horton, E. Danforth, Jr., and E. A. H. Sims. 1983. Thermic effect of infused glucose and insulin in man. Decreased response with increased insulin resistance in obesity and noninsulin-dependent diabetes mellitus. J. Clin. Invest. 72:893-902.

15. Ravussin, E., and C. Bogardus. 1982. Thermogenic response to insulin and glucose infusion: a model to evaluate the different components of the thermic effect of carbohydrate. Life Sci. 31:2011-2018.

16. Acheson, K. J., E. Jéquier, and J. Wahren. 1983. Influence of beta-adrenergic blockade on glucose-induced thermogenesis in man. $J$. Clin. Invest. 72:981-986. 
17. Acheson, K. J., E. Ravussin, J. Wahren, and E. Jéquier. 1984. Thermic effect of glucose in man. Obligatory and facultative thermogenesis. J. Clin. Invest. 74:1572-1580.

18. Durnin, J. V. G. A., and M. M. Rahaman. 1967. The assessment of the amount of fat in the human body from measurements of skinfold thickness. Br. J. Nutr. 21:681-689.

19. Hallman, J., L. O. Farnebo, B. Hamberger, and G. Jonsson. 1978. A sensitive method for the determination of plasma catecholamines using liquid chromatography with electrochemical detection. Life Sci. 23:1049-1052.

20. Hjemdahl, P., M. Daleskog, and T. Kahan. 1979. Determination of plasma catecholamines by high performance liquid chromatography with electrochemical detection comparison with a radio-enzymatic method. Life Sci. 25:131-138.

21. Herbert, V., K. S. Lan, C. W. Gottlieb, and S. J. Bleicher. 1965. Coated charcoal immunoassay of insulin. J. Clin. Endocrinol. Metab. 25:1375-1384.

22. Heindel, J. J., S. W. Cushman, and B. Jeanrenaud. 1974. Cell associated fatty acid levels and energy requiring processes in mouse adipocytes. Am. J. Physiol. 226:16-24.

23. Leemann, T. 1984. Direct determination of R-Metoprolol and S-Metoprolol in biological fluids by ion-pair HPLC. Experientia (Basel). 40:647. (Abstr.)

24. Wall, L. L., Sr., C. W. Gehrke, T. E. Neuner, R. D. Cathey, and P. R. Rexroad. 1975. Total protein nitrogen: evaluation and comparison of four different methods. J. Assoc. Off. Anal. Chem. 58:811-817.

25. Acheson, K. J., Y. Schutz, T. Bessard, E. Ravussin, E. Jéquier, and J. P. Flatt. 1984. Nutritional influences upon lipogenesis and thermogenesis after a carbohydrate meal. Am. J. Physiol. 246:E62-E70.
26. Kolterman, O. G., U. Insel, M. Soekow, and J. M. Olefsky. 1980. Mechanisms of insulin resistance in human obesity. Evidence for receptor and post-receptor defects. J. Clin. Invest. 65:1272-1284.

27. Flatt, J. P. 1978. The biochemistry of energy expenditure. In Obesity Research II. G. A. Bray, editor. Newman Publishing Inc., London. 211-228.

28. DeFronzo, R. A., E. Jacot, E. Jéquier, E. Maeder, J. Wahren, and $E$. Felber. 1981. The effect of insulin on the disposal of intravenous glucose. Results from indirect calorimetry and hepatic and femoral venous catheterization. Diabetes. 20:1000-1007.

29. Bogardus, C., S. Lillioja, K. Stone, and D. Mott. 1984. Correlation between muscle glycogen synthase activity and in vivo insulin action in man. J. Clin. Invest. 73:1185-1190.

30. Newgard, C. B., L. J. Hirsch, D. W. Foster, and J. D. McGarry. 1983. Studies on the mechanism by which exogenous glucose is converted into liver glycogen in the rat. A direct or indirect pathway? J. Biol. Chem. 258:8046-8052.

31. Katz, J., and J. D. McGarry. 1984. The glucose paradox is glucose a substrate liver metabolism? J. Clin. Invest. 74:1901-1909.

32. Thiébaud, D., E. Jacot, R. A. DeFronzo, E. Maeder, E. Jéquier, and J. P. Felber. 1982. The effect of graded doses of insulin on total glucose uptake, glucose oxidation, and glucose storage in man. Diabetes. 31:957-963.

33. Jacot, E., R. A. DeFronzo, E. Jéquier, E. Maeder, and J. P. Felber. 1982. The effect of hyperglycemia, hyperinsulinemia and route of glucose administration on glucose oxidation and glucose storage. Metab. Clin. Exp. 31:922-930.

34. Bogardus, C., S. Lillioja, D. Mott, J. Zawadzki, A. Young, and W. Abbott. 1985. Evidence for reduced thermic effect of insulin and glucose infusions in Pima Indians. J. Clin. Invest. 75:1264-1269. 